\author{
Dariusz Bąk \\ Kozminski University \\ Department of Entrepreneurship and Ethics in Business \\ e-mail:dbak@alk.edu.pl
}

\title{
Czy firma ma sumienie? Refleksje o podmiotowości moralnej organizacji
}

\section{Do companies have a conscience? Reflections on the moral subjectivity of organizations}

Contemporary organizations are one of the most important actors in social life. This is particularly true of business organizations whose activity often has extremely moral consequences. The aim of the paper is to present the problem of moral subjectivity and reflection on the possibility of recognizing an organization as a moral subject. The basis for the considerations were three reference points developed in subsequent parts of the article. The first is the category of moral responsibility. The second concerns the approach of moral subjectivity through the process of moral development. The third point is the category of conscience. Each of these points has been described as an attribute of a moral subject. On the basis of the examples, comments and discussions cited, the arguments for and against the attribution of the organization of moral subjectivity were confronted.

Keywords: moral subject, organization, responsibility, conscience

JEL Classification: M14, Z13 


\section{Wprowadzenie}

Etyka jako dyscyplina filozoficzna ma wymiar wybitnie antropocentryczny. Niezależnie od tego, czy zostanie ujęta w sposób ogólnej refleksji jako sztuka dobrego życia czy bardziej formalnie, jako obszar badania wartości i powinności moralnych - punktem odniesienia zawsze będzie człowiek. Jako indywiduum jest on w stanie identyfikować zjawiska, zdarzenia czy postawy (wliczając w to akty decyzyjne) w kategoriach dobra i zła, co czyni go istotą moralną. Jest też zdolny do podejmowania wolnych i rozumnych wyborów. Sprawstwo w tym zakresie i gotowość do przyjęcia odpowiedzialności za skutki własnych działań jest wyznacznikiem podmiotowości moralnej człowieka.

Człowiek jest też istotą wspólnotową. Egzystuje obok innych i razem z innymi tworzy określoną rzeczywistość społeczną. Immanentną cechą każdej społeczności jest więź moralna, która - jak pisze Piotr Sztompka - skutkuje poczuciem tożsamości, czyli ,autodefinicją własnego miejsca w przestrzeni moralnej i zakreślenia granic przestrzeni moralnej, w której jednostka poczuwa się do powinności zaufania, lojalności i solidarności” (2006, s. 187). Te trzy składniki rzutują na poczucie współuczestnictwa, a tym samym współodpowiedzialności za funkcjonowanie całej grupy. Tak więc moment, gdy jednostka zaczyna posługiwać się kategorią $m y$, do której zalicza swoje ja, jest granicą, od jakiej można zacząć mówić o podmiotowości zbiorowej.

Jedną z form podmiotowości zbiorowej jest organizacja. Co więcej, jak trafnie ujął to Peter F. Drucker (1999), posługując się terminem społeczeństwo organizacji, życie organizacyjne stało się dominującą formą aktywności społecznej. Jednostki działają w organizacjach i poprzez organizacje. Pojęcie organizacji nadaje grupie społecznej określoną specyfikę. Lakoniczna definicja podana w normie ISO 9000: 2000 określa organizację jako grupę ludzi i infrastrukturę z przypisaniem odpowiedzialności, uprawnień i powiazań. Definicja ta jest dość ogólna i nie do końca oddaje celowy charakter tej formy zbiorowości. Bogatsza pod tym względem jest definicja sformułowana przez Tadeusza Kotarbińskiego, który organizację określa jako pewien rodzaj całości ze względu na stosunek do niej jej elementów, mianowicie takiej całość, której wszystkie składniki współprzyczyniają się do powodzenia całości (1958, s. 75).

Ciekawą typologię organizacji proponuje Amitai Etzioni, traktując je jako społeczne instrumenty załatwiania spraw. Wyróżnia następujące typy organizacji (2012, s. 111 i następne):

(1) przymusowe (koercyjne) - zrzeszające członków w sposób niedobrowolny,

(2) normatywne - działające w odniesieniu do celów autotelicznych; związane z podstawowymi potrzebami społecznymi lub wartościami (organizacje publiczne o charakterze edukacyjnym, ochrony zdrowia, fundacje i stowarzyszenia non profit),

(3) utylitarne - typ organizacji zorientowany na cele instrumentalne i korzyści ekonomiczne (przedsiębiorstwa).

Każda organizacja partycypuje w systemie aksjonormatywnym właściwym dla danej zbiorowości. Z drugiej strony jest wyodrębnionym obszarem, który pretenduje do poczucia własnej tożsamości. Sprawia to, że wykształca właściwy sobie system wartości i regulacji, poprzez który manifestuje własną podmiotowość. 
Współcześnie dominująca wydaje się pozycja organizacji utylitarnych. Ten rodzaj organizacji dysponuje specyfiką aksjologiczną ${ }^{1}$, która w ostatnim czasie wydaje się przekraczać własne ramy i wpływa na kształt ogólnej hierarchii wartości społecznych. Homo oeconomicus wypiera pozostałe typy ról i postaw. W dalszej części artykułu rozważania będą skupiały się na tym właśnie typie organizacji.

Z punktu widzenia etyki organizacja pozostaje jednak tworem nie do końca określonym. Jej (etyki) aparat pojęciowy dostosowany jest do opisu/wartościowania działania ludzkiego. Właściwa jest tu więc perspektywa indywidualna, zbudowana na określonej antropologii filozoficznej, a idąc jeszcze dalej - filozofii bytu (cf. Wojtyła, 1969). Organizacja może więc być z powodzeniem definiowana jako zbiór jednostek, z których każda jest realnym, odrębnym podmiotem moralnym. Niemniej jako instytucja jest bytem niesamoistnym, wytworem, instrumentem załatwiania spraw (mówiąc językiem Etzioniego). O ile więc można do organizacji odnosić formy podmiotowości wynikające z uchwycenia pewnego faktu socjologicznego, lub realizacji określonej umowy społecznej (podmiotowość prawna), o tyle przypisywanie jej podmiotowości moralnej wydaje się co najmniej nieuprawnione.

Nie zmienia to faktu, że dostrzec można tendencje do traktowania organizacji, zwłaszcza biznesowej, jak podmiotu moralnego. Jest to zauważalne zwłaszcza w sytuacjach kryzysowych, gdy odnotowywane są społecznie negatywne skutki działań jakichś przedsiębiorstw. Naturalną konsekwencją jest wtedy szukanie winnych, a więc przypisywanie sprawstwa. Jeżeli negatywne skutki, o których mowa, są odbierane jako zło moralne, to sprawca jest traktowany jako podmiot moralny i obarczany takim właśnie rodzajem odpowiedzialności.

Celem artykułu jest przybliżenie problemu podmiotowości moralnej i refleksja nad możliwością ujmowania organizacji jako podmiotu moralnego. Za podstawę rozważań przyjęto trzy punkty odniesienia rozwinięte w kolejnych częściach artykułu. Pierwszym jest kategoria odpowiedzialności moralnej. Drugi dotyczy ujęcia podmiotowości moralnej poprzez proces rozwoju moralnego. Trzecim zaś punktem jest przywołanie kategorii sumienia. Każdy z wymienionych punktów opisany został jako atrybut przynależny podmiotowi moralnemu. W oparciu o przytaczane przykłady, komentarze i dyskusje konfrontowano argumenty za i przeciw przypisywaniu organizacji podmiotowości moralnej.

\footnotetext{
${ }^{1}$ Priorytetowego charakteru nabierają wartości prakseologiczne kojarzone z efektywnością bądź ekonomicznością. Można do nich zaliczyć rentowność, skuteczność, konkurencyjność. Włodzimierz Pańków na przykład wymienia pożądane cechy przedsiębiorstwa, które mogą i powinny być realizowane poprzez dany system wartości utylitarnych i prakseologicznych (Pańków, Rok, Strumińska-Kutra \& Woźniczko, 2010, s. 119-120):

(1) uzyskiwanie trwałej nadwyżki dochodów nad kosztami działalności, w tym - produkcji;

(2) trwała zdolność osiągania celów działalności, czyli pewnych pożądanych stanów rzeczy pod określonymi względami, najlepiej dających się zmierzyć lub przynajmniej zoperacjonalizować;

(3) trwała zdolność do uzyskiwania wymiernego finansowo efektu działalności;

(4) zdolność ograniczania nakładów przeznaczanych na własne funkcjonowanie, w tym - na działalność produkcyjną lub usługową;

(5) zdolność utrzymywania i/lub umacniania własnej pozycji na rynku i uzyskiwania przewagi konkurencyjnej nad innymi organizacjami lub instytucjami.
} 


\section{Kategoria odpowiedzialności moralnej}

Kategoria odpowiedzialności jest definiowana poprzez odwołanie do kryterium wolności i rozumności podmiotu działającego. $Z$ natury rzeczy można założyć, że jest ona przypisana człowiekowi jako jednostce. Można w tym przypadku mówić o odpowiedzialności kompleksowej, która odnosi się do całego spektrum powinności, zaczynając od intuicyjnie ujętej powinności moralnej, a kończąc na jasnej i wyraźnej powinności prawnej. Otwarte pozostaje pytanie, czy tego rodzaju kompleksową podmiotowość można przypisać organizacji (cf. Maclagan, 1998). Nie ma oczywiście wątpliwości co do tych aspektów odpowiedzialności, które wiążą się z realizacją szeroko pojętej umowy społecznej. Istotą problemu jest odpowiedzialność moralna, która w przypadku jednostki jest zakotwiczona w ontycznej strukturze człowieka jako podmiotu moralnego. W przypadku organizacji jest zaś czynnikiem domniemanym i nieoczywistym.

Punktem wyjścia dalszych rozważań niech będą sugestie Romana Ingardena, który wskazał trzy aspekty odpowiedzialności (2004, s. 166):

(1) ktoś jest za coś odpowiedzialny, inaczej mówiąc ponosi za coś odpowiedzialność;

(2) ktoś zostaje za coś przez kogoś pociągnięty do odpowiedzialności;

(3) ktoś bierze na siebie za coś odpowiedzialność.

Dwa pierwsze punkty odpowiadają pojęciu odpowiedzialności restrykcyjnej, w której podmiot jest skonfrontowany z określoną grupą powinności, wynikających z danego systemu normatywnego - w dużej mierze prawa stanowionego. Trzeci punkt nawiązuje do odpowiedzialności powierniczej, która odzwierciedla pewien zakres powinności moralnej. Obrazowo ujmuje to Hans Jonas (1985, s. 93), pisząc:

Gracz, który ryzykuje w kasynie swym majątkiem, postępuje lekkomyślnie; kiedy majątek ten należy nie do niego, lecz do kogoś innego, wtedy postępowanie jego jest przestępstwem; kiedy jednak jest on ojcem rodziny, wtedy postępuje nieodpowiedzialnie, nawet jeśli jego własność jest bezsporna i bez względu też na to, czy przegrywa czy wygrywa (...).

Pomyślność, interes, los innych zostaja, w następstwie zaistnialych okoliczności czy umowy, oddane pod ma piecze, co oznacza, że sprawowanie przeze mnie nadzoru nad nimi zawiera $w$ sobie jednocześnie obowiazek ręczenia za nie. Petnienie tedy tej władzy (mocy) bez baczenia na owo zobowiazanie jest nieodpowiedzialne, oznaczałoby ono zerwanie właściwego dla odpowiedzialności stosunku zawierzenia.

Tak zarysowana kategoria odpowiedzialności powierniczej jest zrozumiała i łatwo identyfikowalna w kontekście wyborów jednostkowych. Sytuacja ulega zmianie w momencie, w którym jest się zmuszonym rozszerzyć zakres znaczeniowy tego, co zostało nam powierzone - czyli przenieść dyskusję na poziom organizacji.

Odpowiedzialność powiernicza w tym zakresie dotyczyłaby gotowości do wypracowania takiego układu relacji z interesariuszami (wewnętrznymi i zewnętrznymi), który zagwarantuje wszystkim zainteresowanym możliwość uczestnictwa w dyskusji nad kształtem organizacji i jej rolą w kreowaniu dobra społecznego. 
W dalszych rozważaniach pomocne mogą się okazać dwa przykłady:

\section{Przykład 1.}

Jak donosi BBC, w 2006 roku były szef spótki France Telecom (działającej od 2013 roku jako Orange), Didier Lombard, ogłosit plany redukcji 22 tysięcy etatów oraz zamiary przeniesienia kolejnych 14 tysięcy pracowników. Celem było zwiększenie efektywności przedsiębiorstwa po tym, jak dwa lata wcześniej spółka została sprywatyzowana. Nie bytoby w tym nic dziwnego, gdyby nie nadzwyczajna determinacja Lombarda, który za wszelka cenę chciat przeprowadzić zwolnienia. Wedlug wewnętrznego dokumentu spółki, na który powołuja się francuskie media, CEO nakazat dyrektorom „pozbycie się" pracowników.

Zarzuty wobec byłego szefa oraz sześciu innych osób, w tym prawej ręki CEO, Louisa-Pierre Wenesa i dyrektora kadr Oliviera Barberota, dotycza podsycania niepokojów i tworzenia nieprzyjemnej atmosfery pracy, która miała przyspieszyć proces redukcji zatrudnienia. W latach 2008-2009, kiedy spółka zlikwidowała tysiace miejsc pracy, zaobserwowano falę samobójstw wśród pracowników i bylych pracowników France Telecom. Faktyczna liczba osób, które targnęty się na swoje życie, nie jest znana, (...) wedlug oficjalnych informacji z prokuratury w ciagu dwóch lat doszło do 31 prób samobójczych, z czego 12 osób udało się uratować. Kolejnych osiem osób zapadło na choroby psychiczne, między innymi na depresję. Na związek samobójstw z redukcją zatrudnienia w France Telecom wskazuja pozostawione listy, w których często pojawiaja się nawiązania do silnej presji ze strony najwyższego kierownictwa (Marchewka, 2016).

\section{Przykład 2.}

Surowica Fav-Afrique koncernu Sanofi Pasteur jest najbardziej uniwersalnym lekiem na świecie - neutralizuje działanie dziesięciu różnych jadów węży. Jej zapasy skończq się w czerwcu 2016 roku. Firma właśnie ogłosiła, że nie wznowi produkcji, bo jest to dla niej nieoptacalne. Popyt na produkt zacząt spadać, a konkurencja z Brazylii, Indii i Meksyku wprowadziła na rynek znacznie tańsze odpowiedniki przeciwko ukąszeniom węży.

Rzecz w tym, że tańsze zamienniki nie sa tak skuteczne i uniwersalne, jak produkt Sanofi Pasteur, który skutecznie radzit sobie z ukaszeniami kobr, mamb i żmij. Właśnie dlatego największe zastosowanie miat w krajach Afryki Subsaharyjskiej, gdzie co roku ponad 30 tys. ludzi umiera z powodu ukąszeń węży, a blisko 10 tys. musi poddać się amputacji pogryzionych kończyn. W większości przypadków ofiary nie mają pojęcia, co ich ukasito, więc antytoksyna o szerokim spektrum działania jest jedyna nadzieja na przeżycie.

- Jesteśmy prywatna firma i sami musimy finansować nasze badania. Jeśli nie mamy przychodów, nie możemy prowadzić badań. Potrzebujemy pieniędzy. Staramy się wyważyć proporcje między ludzkim zdrowiem a zyskami firmy, ale żyjemy w świecie wolnego rynku i musimy być realistami. To okrutny świat - wyjaśnia Alain Bernal, wiceprezes i rzecznik prasowy firmy („Koniec surowicy...”, 2018). 
Obydwa przykłady obrazują działania, które wygenerowały skutki naganne z perspektywy moralnej. Przykład pierwszy dotyczy kształtu relacji z interesariuszami wewnętrznymi. Działania mające na celu restrukturyzację spółki przybrały tu formę opresyjną, noszącą wszelkie znamiona mobbingu organizacyjnego. Jakkolwiek reperkusje prawne dotknęły konkretne osoby z kadry zarządzającej, to firma jako taka znalazła się pod pręgierzem opinii publicznej - odwołującej się do kategorii moralnych.

Przykład drugi odnosi się do interesariuszy zewnętrznych i jest wyrazem zdolności, czy raczej niezdolności firmy do współpracy w zakresie kreowania dobra wspólnego. W tym przypadku pod naciskiem opinii publicznej zdecydowano się na udostępnienie receptury innym podmiotom, które byłyby w stanie przejąć produkcję. Niemniej proces wznowienia produkcji trwałby na tyle długo, że powstałby wielomiesięczny brak zaopatrzenia w stosowny lek z katastrofalnymi skutkami dla potrzebujących. Nie nastąpiło tu naruszenie porządku prawnego. Można również zrozumieć racje ekonomiczne stojące za taką decyzją firmy. Z perspektywy moralnej jednak miało tu miejsce zaniechanie, co wobec negatywnych skutków społecznych zostaje ocenione jako naganne.

W komentarzu do przytoczonych przykładów warto przypomnieć słowa Ulricha Becka, który dostrzega zagrożenie płynące z kierowania się partykularnymi interesami, w oderwaniu od skutków społecznych. W jego ujęciu akceptowalna aktywność biznesowa, firmowana przez system prawny, zapewniająca miejsca pracy, może mieć jednocześnie negatywne konsekwencje społeczne. Beck pisze (2004, s. 44):

Innymi słowy, wysoko zaawansowanemu podziałowi pracy towarzyszy wspólnota w przestęstwie, tej zaś - powszechny brak odpowiedzialności. Każdy jest zarówno przyczyna, jak i skutkiem, a przez to nie jest przyczyna. Przyczyny ulatniaja się w powszechnej zmienności aktorów i warunków, reakcji i przeciwreakcji. Nadaje to myśleniu systemowemu społeczna oczywistość i popularność. (...) można działać bez końca, nie ponoszac osobistej odpowiedzialności. Człowiek działa, jak gdyby będac nieobecnym. Działa w sensie fizycznym, nie działając jednocześnie ani moralnie, ani politycznie. W człowieku i przez człowieka działa uogólniony Inny - system.

Jeżeli zamiast terminu system wpisać termin organizacja, można już określić przedmiot dyskusji: Czy moralne skutki działalności organizacji/przedsiębiorstw spadają na organizację jako całość (stawiając ją w roli podmiotu moralnego)? Czy też należy traktować organizację jako zespół osób, z których każda jest odrębnym podmiotem moralnym, ponoszącym konsekwencje własnych decyzji?

\section{Dyskusja}

Problem próbuje w ciekawy sposób rozwiązać Ronald Dworkin (2006), dopatrując się przede wszystkim spontanicznej i w jakiejś mierze naiwnej personifikacji zjawisk bądź instytucji, do której dochodzi wskutek upraszczania poznawczego. Myśląc na przykład o firmie, zakłada się określoną całość. Jest konkretyzowana i sprowadzana do pewnej 
„ontycznej” jedności. W świadomości odbiorcy nie funkcjonuje jako organizacja złożona $\mathrm{z}$ wielu odrębnych jednostek, działających zgodnie z własnymi procedurami i partykularnymi celami.

Kolejnym etapem na drodze personifikacji jest podmiotowość prawna, która w ramach rozwiązań instytucjonalnych narzuca organizacji określony charakter (zespół praw i powinności) $\mathrm{w}$ relacjach $\mathrm{z}$ innymi podmiotami. Te dwa czynniki przyczyniają się do prób traktowania organizacji jako podmiotu również w kontekście moralnym. Dworkin analizuje tę opcję poprzez nawiązanie do kategorii odpowiedzialności odszkodowawczej w przypadku naruszenia dóbr osób trzecich (klientów firmy). Odwołuje się tu do kazusu producenta wadliwych samochodów, gdzie na skutek defektu śmierć lub uszczerbek na zdrowiu ponosi pewna liczba osób ${ }^{2}$. Roszczenia osób poszkodowanych lub ich bliskich powinny w oczywisty sposób odnosić się do tych pracowników firmy, którzy w mniej lub bardziej bezpośredni sposób przyczynili się do powstania defektu lub zaniechania jego usunięcia. Droga taka może być jednak problematyczna, gdy uświadomić sobie, że poszczególne osoby czy działy zaangażowane w proces przygotowania projektu, wdrożenia go do produkcji, promocji i sprzedaży nie musiały w sposób konieczny, a czasem nie mogły dysponować całościowym oglądem problemu, który pozwoliłby im na indywidualne odczucie powinności moralnej i adekwatną reakcję.

Trawestując Dworkina, można wskazać na zjawisko horyzontu aksjologicznego. Otóż - zgodnie z wcześniejszym założeniem - warunkiem podmiotowości moralnej jednostki jest wolność oraz świadomość co do przesłanek i konsekwencji podejmowanej decyzji. Widząc bądź przewidując skutki swoich działań, można wziąć za nie moralną odpowiedzialność. Zaaprobować je bądź uznać swoją winę i zadośćuczynić potencjalnym poszkodowanym. Może się jednak zdarzyć, że skutki pewnych decyzji są oddalone od sprawcy w czasie lub przestrzeni, a tym samym ich świadomość zaciera się lub w ogóle nie jest brana pod uwagę. Przypadek braku przesłanek do powątpiewania o słuszności decyzji Tadeusz Ślipko określa jako niewiedzę niepokonalna (2004, s. 85). Stan taki znosi odpowiedzialność moralną, w odróżnieniu od niewiedzy pokonalnej, którą cechuje element niepewności, czyli dyskomfort poznawczy, ujawniający powinność sprawdzenia wszystkich okoliczności towarzyszących potencjalnej decyzji. Dużą rolę odgrywają tu takie sformułowania, jak ,obawa” czy ,uzasadnione podejrzenie”. Istnienie horyzontu aksjologicznego każe dostrzec znaczenie informacji dla sądów wartościujących. Co więcej, ukazuje zależność między zakresem posiadanej wiedzy a ciężarem odpowiedzialności i trudnością podjęcia wyboru.

\footnotetext{
${ }^{2}$ Dworkin nie pisze tego wprost, niemniej można przypuszczać, że odwołuje się bezpośrednio do głośnych spraw w amerykańskim przemyśle motoryzacyjnym. Problem chevroleta corvair, produkowanego przez General Motors, którego błędy konstrukcyjne spowodowały śmierć wielu osób, opisany został w głośnej książce Unsafe At Any Speed z 1965 r. Bezpośrednią konsekwencją afery było przyjęcie ustawy o ruchu drogowym i bezpieczeństwie pojazdów, a następnie powołanie Departamentu Transportu oraz Rządowej Agencji Bezpieczeństwa Ruchu Drogowego (National Highway Traffic Safety Administration). Kolejna głośna sprawa dotyczyła forda pinto, produkowanego w latach 1971-1980. Samochód wprowadzono na rynek mimo wiedzy o błędzie konstrukcyjnym i ze świadomością niższych standardów bezpieczeństwa, które jednak nie naruszały obowiązujących wówczas norm NHTSA. Ford przeprowadził dość szokującą kalkulację przewidywanych kosztów wypadków, uznając je jednocześnie za niewystarczający argument ekonomiczny do poprawienia konstrukcji auta, co zminimalizowałoby ryzyko śmierci lub utraty zdrowia kierowców i pasażerów (http://egocar. pl/2015/12/niebezpieczne-przy-kazdej-predkosci/ (data dostępu: 13.04.2016; Shaw, 1996))..
} 
Dworkin, opisując moralną niejednoznaczność kategorii odpowiedzialności indywidualnej, wskazuje na możliwość istnienia winy bez sprawcy. Sytuacja taka nie jest w żaden sposób logicznie uprawomocniona i domaga się jakiejś formy uzasadnienia. W tym celu odwołuje się do następujących argumentów:

(1) zasady kontraktu właścicielskiego. Akcjonariusze, akceptując korzyści płynące z działalności firmy, muszą zgodzić się na przyjęcie wszystkich konsekwencji płynących z tej działalności, również negatywnych: Zakładamy, że przedsiębiorstwo musi być traktowane jak podmiot moralny, a następnie stosujemy doń wzorce naszych zasad, dotyczacych czynów indywidualnych i odpowiedzialności za nie. Moglibyśmy powiedzieć, że ktokolwiek w petni kontrolowat produkcję wadliwego produktu, ponosi obowiazek wypłacenia odszkodowania osobom, które z tego powodu poniosty szkodę. Żaden pojedynczy akcjonariusz lub pracownik nie sprawowat takiej kontroli, ale sprawowało ja przedsiębiorstwo (Dworkin, 2006, s. 171).

(2) zakładanej odpowiedzialności zbiorowej, do czego dochodzi zarówno po stronie zewnętrznych interesantów, jak i bezpośrednich członków organizacji. W pierwszym przypadku jest to akt spontanicznej personifikacji grupy, w stosunku do której kieruje się intencjonalne rozpoznanie. Perspektywa klienta nie skupia się na organizacyjnej różnorodności, ale szuka jednego, ogólnego punktu odniesienia. Hipotetyczny sprzedawca staje się jednostkową manifestacją większej, enigmatycznej całości. Formuła typu ,,pracownik działu sprzedaży firmy X wprowadził mnie w błąd” zostaje zastąpiona formułą ,zostałem oszukany przez firmę X". Perspektywa członka organizacji jest z kolei uwikłana w poczucie przynależności do wspólnoty. Dworkin podaje przykłady społeczności, w których przez długi czas odzywało się poczucie wstydu za „grzechy przodków”.

\section{Kategoria rozwoju moralnego}

Jedną z ciekawszych koncepcji w obrębie omawianego problemu jest możliwość zastosowania koncepcji rozwoju moralnego do wyznaczenia stopnia dojrzałości przedsiębiorstwa w zakresie etyki i odpowiedzialności społecznej. Joanne M. Logsdon i Kristi Yuthas (1997) na przykład przenoszą koncepcję rozwoju moralnego na obszar organizacji, zakładając, że jest ona podatna na zmiany w zakresie świadomości i standardów etycznych. Zmiany te są kontrolowalne i mogą przybrać postać procesu opisywanego przez Lawrence'a Kohlberga.

Kohlberg (1981) przedstawił bardzo obrazową wizję kształtowania indywidualnej refleksji moralnej. Wskazał trzy, różniące się między sobą, momenty, które określił jako stadia: przedkonwencjonalne, konwencjonalne i postkonwencjonalne.

W stadium przedkonwencjonalnym jednostka podejmuje wybory, opierając się na dwóch podstawowych typach motywacji: naiwnym hedonizmie oraz mechanicznym wyborze pomiędzy nagrodą a karą. W opisie tego stadium pobrzmiewają echa Hobbesowskiej koncepcji człowieka jako jednostki egotycznej oraz kierowanej uczuciami strachu 
przed porażką i nadziei na przyjemność/korzyść. Kolejne stadium akcentuje zdolność jednostki do podporządkowania się reżimowi norm i standardów postępowania, narzuconych przez grupę, do której jednostka ma aspiracje przynależeć. Reguły grupy, początkowo odbierane jako zewnętrzne i restrykcyjne, przechodzą w fazę internalizacji, ujawniając się na przykład jako „głos sumienia”. Stadium postkonwencjonalne jest etapem autonomizacji świadomości moralnej. W tym przypadku jednostka akcentuje swoją podmiotowość, która nie jest już tylko założeniem teoretycznym (in spe), lecz w pełni urzeczywistnia postulat rozumności i wolności, tj. pełnej autonomii podmiotu działającego.

Możliwość zastosowania koncepcji rozwoju moralnego do budowania tożsamości przedsiębiorstwa obrazuje poniższy przykład przedstawiony na podstwie informacji zamieszczonych na stronie firmy Canon (www.canon.pl).

\section{Przyklad 3.}

Kyosei to firmowa filozofia Canon leżaca u podstaw naszej marki, biznesu i aktywności sponsorskich. Kyosei to japońskie słowo oznaczająe wspólne życie i pracę dla wspólnego dobra - zasadę wcielanq w życie przez wszystkich pracowników Canon. Wyznacza ona misję i wartości, sposób, w jaki traktujemy pracowników i prowadzimy interesy.

Oprócz działań naszej firmy, Kyosei wpływa na sposób, w jaki działamy w szerszej społeczności oraz z organizacjami na catym świecie. Wierzymy, że bycie dobrym korporacyjnym obywatelem ma najwyższa wage i myślimy o wptywie naszych działań na naszych klientów, pracowników, partnerów i świat wokót nas.

W komentarzu do przykładu warto przytoczyć charakterystykę ścieżki Kyosei opisaną przez Agatę Rudnicką. Autorka zaznacza, że:

filozofia Kyosei opiera się na założeniu, że podmiot gospodarczy ewoluuje w czasie i staje się bardziej dojrzaty. Znajduje to odzwierciedlenie w zmianie podejścia firmy-od relacji wewnętrznych do ukierunkowania zewnętrznego (...) Kyosei to pięć poziomów, które powinna osiagnać organizacja. Sa one tożsame z piramida potrzeb Maslowa: od poziomu podstawowego, na którym organizacja zapewnia sobie warunki do funkcjonowania, do poziom odpowiadającego samorealizacji. Ścieżka Kyosei to symbol dojrzałości organizacji, która swoja działalność postrzega przez pryzmat dobra wspólnego. Jako alternatywa tradycyjnego sposobu zarządzania może stać się propozycją dla firm, które krok po kroku porzadkuja swoje procesy, dążac do maksymalizowania dobra ogólnoświatowego poprzez udział w rozwiązywaniu problemów społecznych, bez poświęcania jednak podstawowej wartości, jaka jest pomnażanie własnych zysków (Rudnicka, 2012, s. 68-69; cf. Filimon, 2009). 


\section{Dyskusja}

U podstaw tego typu analiz leży uznany implicite podmiotowy charakter organizacji. Nadana organizacji podmiotowość moralna budzi jednakże szereg zastrzeżeń. Wydaje się, że analogiczne przeniesienie atrybutów podmiotowości człowieka na wymiar organizacji nie do końca jest uzasadnione. Głównym argumentem przeciw byłaby kategoria integralności. Niezależnie od tego, czy do problemu natury ludzkiej podchodzi się z perspektywy antropologii filozoficznej czy psychologii, zakłada się integralną wizję osobowości człowieka. Ukazany na przykład w fenomenologii strumień świadomości jest nieprzerwanym ciągiem następujących po sobie aktów poznawczych, które przekładają się na doświadczenie jednostkowej tożsamości. W perspektywie aksjologicznej zmienna percepcja wartości jest zakotwiczona w niezmiennej strukturze ontycznej człowieka.

Wydaje się, że tego rodzaju bytowej integralności nie można przenieść na strukturę organizacji. Proces rozwoju moralnego, na który wskazuje Kohlberg, jest co do zasady nieodwracalny. Trudno wyobrazić sobie człowieka, który, osiągnąwszy pozycję autorytetu moralnego w stadium postkonwencjonalnym, cofnąłby się do stadium egoistycznego hedonizmu. Nawet jeżeliby przyjąć odwracalność omawianego procesu, to zjawisko takie byłoby raczej incydentalne i uwikłane w szereg trudnych do zidentyfikowania determinacji. Inna sprawa, że - zdaniem Kohlberga - jedynie około jednej czwartej populacji ma szansę osiągnąć poziom postkonwencjonalny w rozwoju moralnym. W przypadku organizacji mamy do czynienia ze zbyt dużą liczbą zmiennych. Każda organizacja zrzesza osoby, które realizują w niej również cele indywidualne i co do swej istoty pozaorganizacyjne. Każdy z członków organizacji wnosi do niej bagaż własnych doświadczeń oraz sobie tylko właściwych ocen, preferencji i standardów moralnych. Doprowadzenie tak rozproszonych podmiotów do pełnej integralności moralnej, zorientowanej na cele organizacyjne, mogłoby spowodować moralną dezintegrację na poziomie jednostkowym.

Przy założeniu, że organizacja jest obszarem przestrzeni społecznej, można co najwyżej założyć, że za pośrednictwem kultury organizacyjnej można wpływać na charakter przyjętej konwencji. W takim przypadku zmiany w układzie obowiązujących norm i wartości organizacyjnych mogą kreować indywidualny rozwój moralny członków organizacji i w konsekwencji przekładać się na etyczną wartość decyzji podejmowanych w organizacji i w imieniu organizacji. W zależności od poziomu zbiorowej świadomości moralnej firma może przyjmować określone standardy postępowania $\mathrm{w}$ zakresie zachowań rynkowych, jak też odpowiedzialności społecznej (Lewicka-Strzałecka, 1999). W literaturze można spotkać typologie ról, jakie może odegrać organizacja w kontekście wypełnianych celów ekonomicznych i społecznych. Można tu wyróżnić firmy, dla których aktywność w sferze społecznej traktowana jest jako: (a) zagrożenie, (b) przeszkoda w osiąganiu zysku, (c) nie jest w kręgu zainteresowań, (d) dobrowolne przyjęcie odpowiedzialności, (e) świadomość interakcyjnych powiązań, (f) kształtowanie infrastruktury społecznej i dostarczanie innowacji, (g) dostarczanie pozaekonomicznych dóbr i usług (cf. Johnson \& Scholes, 1993).

Jakkolwiek można zgodzić się z powyższymi opisami sugerującymi różny stopień zaangażowania w sferę dobra wspólnego (co można porównać do stopnia dojrzałości moralnej), o tyle trudniejsze do przyjęcia jest założenie, że wyszczególnione typy ról mogą 
przyjmować charakter etapów jakiegoś procesu rozwoju moralnego. Wydaje się raczej, że organizacja może przyjąć dowolny format postawy moralnej, na miarę indywidualnego zaangażowania i dojrzałości moralnej swoich członków. Jest zdolna do scalenia etycznych postaw i przekonań pracowników i przetworzenia ich w nową jakość, wyrażoną w elementach kultury organizacyjnej i zachowaniach rynkowych. Niemniej jest to jakość o charakterze akcydentalnym i zmiennym, nazbyt uzależnionym od rotacji personalnych, zmian rynkowych, koniunktury i szeregu innych czynników.

\section{Kategoria sumienia}

Pojęcie sumienia jest mocno zakorzenione w języku potocznym i odnosi się zazwyczaj do pewnej formy świadomości moralnej lub dyskomfortu moralnego wynikającego z poczucia winy. Jest również uwikłane znaczeniowo w kontekst etyki i teologii chrześcijańskiej.

W obrębie etyki funkcjonuje osobny dział zajmujący się zagadnieniem sumienia i nosi nazwę synejdezjologii. Jest on wynikiem dostrzeżenia rozdźwięku, jaki może się pojawić między ujawnioną i uznaną za obowiązującą powinnością moralną a wyborem/działaniem konkretnego podmiotu moralnego. Problem polega na tym, że w teoriach etycznych podmiot jest zazwyczaj opisywany przez abstrakcyjnie ujętą rozumność czy autonomię. W praktyce kategorie te są jedynie dyspozycjami, z których w większym lub mniejszym stopniu korzysta człowiek osadzony w dowolnym kontekście życiowym, w różnych stanach emocjonalnych, zdolny do błędów poznawczych i interpretacyjnych. Sumienie jawi się w tym przypadku jako wewnętrzny (i subiektywny) „osąd o moralnym dobru/złu zamierzonego przez człowieka konkretnego aktu, którego zrealizowanie stanie się dlań źródłem wewnętrznej aprobaty lub poczucia winy, własnego bycia dobrym lub złym człowiekiem" (Ślipko, 2004, s. 377). Dyskusja nad podmiotowością moralną przedsiębiorstwa rodzi pokusę skorzystania z analogii i odwzorowania innych atrybutów przypisywanych podmiotowi moralnemu. Przedsiębiorstwo jest z całą pewnością wolne i autonomiczne W zakresie swych aktywności i kształtowania relacji z otoczeniem. W racjonalny sposób organizuje swą strukturę wewnętrzną, wyznacza cele i ocenia konsekwencje. Pozostaje pytanie, czy posługując się analogią i uznając podmiotowość moralną organizacji, uprawnione jest operowanie wobec przedsiębiorstwa pojęciem sumienia.

Przesłanką skłaniającą do myślenia o możliwości przeniesienia kategorii sumienia na płaszczyznę organizacji jest opisana wcześniej wizja organizacji w procesie dojrzewania moralnego. Związek sumienia z dojrzałością moralną dostrzega na przykład nestor etyki biznesu Timothy DeGeorge (1995, s. 119, za: Gasparski, 2007, s. 243), pisząc:

Rozwijając się, ludzie nabywaja wzoru działania i dyspozycji do działania w pewien sposób. Dyspozycje te traktowane tacznie bywaja nazywane charakterem. Osoba, która zwykle dązy do działania zgodnego z tym, jak powinna moralnie to czynić, ma dobry charakter. Jeśli nie ulega silnym pokusom, to ma silny charakter. Jeśli zazwyczaj postępuje niemoralnie, to ma zły charakter. Jeśli, mimo dobrych intencji często ulega 
pokusom, to ma staby charakter. Ponieważ charakter tworzony jest w wyniku świadomych działań, to ludzie odpowiedzialni sa zarówno za swój charakter, jak i swe poszczególne działania.

Sumienie to zdolność do moralnego wnioskowania w sprawach moralności dziatań, angażującego zbiór wartości, odczuć i dyspozycji, by wykonać pewne działania lub ich nie wykonywać (...). Jesteśmy moralnie zobligowani do tego, by działać w zgodzie $z$ własnym sumieniem oraz $w$ równym stopniu do tego, by rozwijać obiektywne i poprawne sumienie.

Jeżeli przyjąć, że organizacja jest w stanie dokonać aktu autorefleksji i zarządzać procesem samodoskonalenia w aspekcie standardów etycznych i świadomości moralnej, wypada uznać podmiotowość organizacji w tym zakresie (sumienie jako zdolność formowania dojrzałości moralnej).

Druga przesłanka dotyczy różnicy, jaka zachodzi pomiędzy teoretycznym ujęciem powinności moralnej a realnym działaniem. W rzeczywistości spotykamy się z konkretnymi organizacjami o mniej lub bardziej zaawansowanej kulturze organizacyjnej czy wykształconej tożsamości, funkcjonującymi w konkretnych warunkach społeczno-gospodarczych i w określonym kontekście prawnym. Naturalny jest więc dysonans, jaki może pojawić się między poczuciem powinności a tym, jak organizacja przetworzy je wobec zaistniałych wyzwań (sumienie jako zdolność do konfrontowania własnych działań ze spodziewaną oceną).

Trzecia przesłanka odnosi się do kategorii odpowiedzialności i poczucia sprawstwa w zakresie moralnych skutków własnej działalności. Jest to zdolność do odczuwania winy (samokrytyka) lub aprobaty wobec podejmowanych działań.

W przypadku każdej z powyższych przesłanek można podać stosowne przykłady. Będą to misje i kodeksy wartości czy też zaangażowanie w obszarze społecznej odpowiedzialności biznesu. Innym dowodem jest stosowanie narzędzi pozwalających tak zarządzać organizacją, by unikać działań, które mogą spotkać się z negatywną oceną społeczną. Rolę tę zaczęły spełniać działy compliance, których zadaniem stała się profilaktyka aktywności organizacji w kontekście potencjalnego naruszenia obowiązujących standardów prawnych, etycznych i innych norm społecznych. Groźba potencjalnych sankcji prawnych jest co prawda o wiele wyrazistsza niż enigmatyczne i niejednoznaczne sankcje moralne. Tak czy inaczej, odniesienie się do szerokiego spektrum powinności i dbałość o działania zgodne z obowiązującymi normami jest tym, czego wymaga się od sprawnie działającego systemu compliance. Jest on więc działaniem przynależącym do obszaru etyki, pełniącym w przedsiębiorstwie rolę analogiczną do tego, jaką spełnia sumienie w podmiocie moralnym.

Istnieje oczywiście szereg wątpliwości. Organizację, która jest zbiorem indywidualnych podmiotów moralnych, trudno ujmować jako podmiot odrębny lub uznać jej hiperpodmiotowość. Traktując firmę jako zbiorowość, nie ma podstaw do przypisania jej na przykład odpowiedzialności moralnej. Wojciech Gasparski przytacza argumentację Mario Bungego, według której nie istnieje moralna odpowiedzialność zbiorowa, gdyż tylko osoba może mieć sumienie. Wprawdzie złe organizacje czy złe społeczeństwa mogą stwarzać klimat sprzyjający złemu zachowaniu, ale to poszczególne indywidua, a nie zbiorowości ponoszą odpowiedzialność moralną za swoje czyny bądź zaniechania. Bun- 
ge wprowadza w tym miejscu odnoszące się do organizacji pojęcie accountability (obliczalność) w miejsce właściwej człowiekowi responsibility (Bunge, 1988, s. 108-110; cf. Gasparski, 2007, s. 240).

W odpowiedzi można stwierdzić, że jakkolwiek w przypadku organizacji trudno mówić o jedności ontologicznej właściwej człowiekowi, o tyle z całą pewnością można zaakceptować jedność funkcjonalną, która ma zakotwiczenie w integralności struktury wewnętrznej, poczuciu tożsamości organizacyjnej oraz fakcie, że organizacja działa jako formalna całość. A co więcej, jej działalność przynosi konkretne konsekwencje moralne.

Jeżeli więc nawet nie da się obronić tezy, że organizacja jest podmiotem moralnym, to $\mathrm{z}$ całą pewnością wciela się ona w rolę podmiotu moralnego - i przyjmuje na siebie (czy tego chce czy nie) tego rodzaju odpowiedzialność.

\section{Podsumowanie}

Etyka jest racjonalną refleksją nad fenomenem moralności. W centrum jej zainteresowań jest człowiek/osoba/podmiot moralny. Doświadcza on poczucia powinności. Podejmuje decyzje i ponosi odpowiedzialność za ich konsekwencje. Wartościuje i ocenia, mając na względzie dobro i zło własnego postępowania (jednocześnie sam podlega ocenie).

Moralna ocena funkcjonowania organizacji jest już narażona na szereg wątpliwości. Czy moralność organizacji jest wypadkową świadomości moralnej jej członków czy raczej ma charakter samoistny? Pewne jest, że organizacja, działając jako całość, generuje skutki nie tylko o charakterze ekonomicznym, ale również moralnym. Wskazano też, że skutki działań organizacji jako takiej wykraczają poza jednostkowe sprawstwo, a tym samym indywidualną odpowiedzialność członków organizacji. Odpowiedzialność moralną należałoby więc przypisać organizacji jako całości. Skądinąd wiadomo, że jedynie podmiot moralny może ponosić tego rodzaju odpowiedzialność. Czy zatem organizacji/ przedsiębiorstwu można przypisać podmiotowość moralną?

Z perspektywy filozoficzno-etycznej jest to nie do przyjęcia. Każda organizacja jest wytworem i zbiorem odrębnych jednostek. I pomimo funkcjonalnych i strukturalnych podobieństw, chętnie akcentowanych przez teoretyków organizacji (cf. Morgan, 1999), nie dysponuje wewnętrzną integralnością adekwatną do integralności osoby ludzkiej.

Inaczej rzecz ma się z perspektywy etyczno-psychologicznej. W tym przypadku problem dotyczy nie tego, że organizacja jest podmiotem, ale że jest uważana za podmiot moralny. Jest faktem, że przedsiębiorstwo samo wciela się w rolę podmiotu moralnego, występując wobec interesariuszy jako podmiot o określonej tożsamości, systemie wartości i partner, któremu można zaufać. Więź moralna ujawniona przez fakt dobrowolnej kooperacji ma szczególne znaczenie dla etyki życia gospodarczego. Jest to uzasadnione rolami, jakie organizacja gospodarcza pełni w strukturze społecznej:

(1) Jest obszarem przestrzeni moralnej dla swoich członków. W organizacji i za pośrednictwem jej struktur wewnętrznych jednostki mogą realizować swoje podstawowe potrzeby. W organizacji uzgadniane są sposoby, za pomocą których 
potrzeby te są osiągane, dzięki czemu staje się ona przestrzenią moralną z wyartykułowanymi standardami sprawiedliwości, przyzwoitości i rzetelności. Suma określonych relacji osobowych i profesjonalnych kształtuje kulturę organizacyjną, a poprzez nią organizacja w mniej lub bardziej świadomy sposób wpływa na „dojrzałość” moralną swoich członków. Należy przez to rozumieć ich przekonania moralne, zdolność do świadomego i autonomicznego określania własnej hierarchii wartości, gotowość realizacji tych wartości i zdolność sprzeciwu wobec naruszania przyjętych standardów.

(2) Jest podmiotem życia społecznego. Jest funkcjonalną jednością, która definiuje własne cele i wybiera sposoby ich realizacji. Skutki działań organizacji jako całości dotykają innych uczestników życia społecznego, zarówno jednostki, jak i zbiorowości. Odpowiedzialność (co najmniej moralna) za te skutki spada na organizację. Poprzez swoje działania organizacja wpływa na charakter przestrzeni moralnej, inicjując kulturę zaufania lub kulturę nieufności. Współdzieląc przestrzeń moralną, musi dostosować się do wymogów narzucanych przez innych członków zbiorowości (tak jednostki, jak i organizacje). Bierze czynny udział w tworzeniu i podtrzymywaniu umowy społecznej oraz określonego porządku aksjonormatywnego.

W kontekście powyższego uzasadnione wydaje się wprowadzenie pojęcia quasi-podmiotowości moralnej organizacji.

\section{Bibliografia}

Beck, U. (2004). Społeczeństwo ryzyka. W drodze do innej nowoczesności (S. Cieśla, tłum.). Warszawa: Wydawnictwo Naukowe SCHOLAR.

Bunge, M. (1988). Treatise on Basic Philosophy. Ethics: The Good and the Right (vol. 8). Dordrecht: D. Reidel Publishing Company.

Drucker, P.F. (1999). Społeczeństwo pokapitalistyczne (G. Kranas, tłum.). Warszawa: Wydawnictwo Naukowe PWN.

Dworkin, R. (2006). Imperium prawa. Warszawa: Wolters Kluwer.

Etzioni, A. (2012). Aktywne społeczeństwo (S. Burdziej, tłum.). Kraków: Zakład Wydawniczy NOMOS.

Filek, J. (red.). (2004). Filozofia odpowiedzialności XX wieku. Teksty źródtowe. Kraków: Wydawnictwo UJ.

Filimon, I.A. (2009). Kyosei - an Example of Cultural Keyword Argumentatively Exploited in Corporate Reporting Discourse. Studies in Communication Sciences, 9(2), 131-151.

Gasparski, W. (2007). Wyklady z etyki biznesu. Warszawa: Wydawnictwo WSPIZ.

George, R.T. de (1995). Business Ethics. New Jersey: Prentice Hall.

Ingarden, R. (2004). Ontyczne podstawy odpowiedzialności. W: J. Filek (red.), Filozofia odpowiedzialności XX wieku. Teksty źródłowe. Kraków: Wydawnictwo UJ.

Johnson, G., \& Scholes, K. (1993). Exploring Corporate Strategy. New York: Prentice Hall.

Jonas, H. (1985). The Imperative of Responsibility: In Search of an Ethics for the Technological Age. Chicago \& London: The University of Chicago Press. 
Kohlberg, L. (1981). Essays on Moral Development, The Philosophy of Moral Development: Moral Stages and Idea of Justice (vol. 1). New York: Harper \& Row.

Koniec surowicy na jad węży. „Ludzie będą ginąć i tracić kończyny”. (2018, 22 lutego). Newsweek Polska. http://www.newsweek.pl/swiat/sanofi-pasteur-koniec-surowicy-fav-afrique-ukaszenia-wezy-,artykuly,370256,1.html

Kotarbiński, T. (1958). Traktat o dobrej robocie. Wrocław: Ossolineum.

Lewicka-Strzałecka, A. (1999). Etyczne standardy firm i pracowników. Warszawa: Wydawnictwo IFiS PAN.

Logsdon, J.M., \& Yuthas, K. (1997). Corporate Social Performance, Stakeholder Orientation, and Organizational Moral Development. Journal of Business Ethics, 16(12/13), 1213-1226.

Maclagan, P. (1998). Management and morality. Thousand Oaks: Sage Publications Ltd.

Marchewka, M. (2016). Byłe kierownictwo France Telecom odpowie za samobójstwa pracowników? Portal „Co słychać w biznesie”. http://www.coslychacwbiznesie.pl/biznes/byle-kierownictwo-france-telecom-odpowie-za-samobojstwa-pracownikow

Morgan, G. (1999). Obrazy organizacji (Z. Wiankowska-Ładyka, tłum.). Warszawa: Wydawnictwo Naukowe PWN.

Pańków, W., Rok, B., Strumińska-Kutra, M., \& Woźniczko, J. (2010). Oblicza społecznej odpowiedzialności przedsiębiorstw. Warszawa: Wydawnictwo Naukowe SCHOLAR.

Rudnicka, A. (2012). CSR - doskonalenie relacji społecznych w firmie. Warszawa: Oficyna Wolters Kluwer.

Shaw, W.H. (1996). Business Ethics. Belmont: Wadsworth Publishing Company.

Sztompka, P. (2006). Socjologia. Analiza społeczeństwa. Kraków: Wydawnictwo Znak.

Ślipko, T. (2004). Zarys etyki ogólnej. Kraków: Wydawnictwo WAM.

Wojtyła, K. (1969). Osoba i czyn. Kraków: Polskie Towarzystwo Teologiczne.

http://egocar.pl/2015/12/niebezpieczne-przy-kazdej-predkosci/

https://www.canon.pl/about_us/about_canon/philosophy/ 